\title{
Seasonal variations in physical characteristics of aerosol particles at the King Sejong Station, Antarctic Peninsula
}

\author{
Jaeseok Kim ${ }^{1}$, Young Jun Yoon ${ }^{1}$, Yeontae Gim ${ }^{1}$, Hyo Jin Kang ${ }^{1,2}$, Jin Hee Choi ${ }^{1}$, Ki-Tae Park ${ }^{1}$, and Bang Yong Lee ${ }^{1}$ \\ ${ }^{1}$ Korea Polar Research Institute, 26 Songdomirae-ro, Yeonsu-gu, Incheon 21990, South Korea \\ ${ }^{2}$ University of Science \& Technology (UST), 217 Gajeong-ro, Yuseong-gu, Daejeon 34113, South Korea \\ Correspondence to: Young Jun Yoon (yjyoon@kopri.re.kr)
}

Received: 2 September 2016 - Discussion started: 27 October 2016

Revised: 12 September 2017 - Accepted: 26 September 2017 - Published: 3 November 2017

\begin{abstract}
Seasonal variability in the physical characteristics of aerosol particles sampled from the King Sejong Station in the Antarctic Peninsula was investigated over the period between March 2009 and February 2015. Clear seasonal cycles for the total particle concentration $(\mathrm{CN})$ were observed. The mean monthly concentration of particles larger than $2.5 \mathrm{~nm}$ $\left(\mathrm{CN}_{2.5}\right)$ was highest during the austral summer, with an average value of $1080.39 \pm 595.05 \mathrm{~cm}^{-3}$, and lowest during the austral winter, with a mean value of $197.26 \pm 71.71 \mathrm{~cm}^{-3}$. The seasonal patterns in the concentrations of cloud condensation nuclei $(\mathrm{CCN})$ and $\mathrm{CN}$ coincide, with both concentrations being at a minimum in winter and maximum in summer. The measured $\mathrm{CCN}$ spectra were approximated by fitting a power-law function relating the number of $\mathrm{CCN}$ for a given supersaturation (SS) to each SS value, with fitting coefficients $C$ and $k_{T}$. The values for $C$ varied from 6.35 to $837.24 \mathrm{~cm}^{-3}$, with a mean of $171.48 \pm 62.00 \mathrm{~cm}^{-3}$. The values for $k_{T}$ ranged from 0.07 to 2.19 , with a mean of $0.41 \pm 0.10$. In particular, the $k_{T}$ values during the austral summer were higher than those during the winter, indicating that aerosol particles are more sensitive to SS changes during summer. Furthermore, the annual mean hygroscopicity parameter, $\kappa$, was estimated as $0.15 \pm 0.05$, for a SS of $0.4 \%$. The effects of the origin and pathway travelled by the air mass on the physical characteristics of the aerosol particles were also determined. The modal diameter of aerosol particles originating in the South Pacific Ocean showed a seasonal variation varying from $0.023 \mu \mathrm{m}$ in winter to $0.034 \mu \mathrm{m}$ in summer for the Aitken mode, and from $0.086 \mu \mathrm{m}$ in winter to $0.109 \mu \mathrm{m}$ in summer for the accumulation mode.
\end{abstract}

\section{Introduction}

Aerosol particles in the atmosphere are either emitted directly from various natural and anthropogenic sources (primary aerosol particles) or produced by gas-to-particle conversion processes (secondary aerosol particles). These particles influence the local and global climates directly by scattering and absorbing radiation and indirectly by acting as cloud condensation nuclei (CCN) or ice nuclei (IPCC, 2013). The physical, chemical, and optical properties of atmospheric aerosol particles determine their impact on climate change. Although various studies on the effects of aerosol particles on climate change have been conducted, specific direct and indirect climate effects are still uncertain (IPCC, 2013). Moreover, in order to understand the sources and processes related to atmospheric aerosols, long-term observations for different regions are required because aerosol particles vary temporally and spatially.

The Antarctic region is highly sensitive to climate change due to complex interconnected environmental systems such as snow cover, land ice, sea ice, and ocean circulation (Chen et al., 2009). Previous studies have shown that Antarctica and the Antarctic Peninsula have experienced significant climate changes (Rignot et al., 2004; Steig et al., 2009; Pritchard et al., 2012; Schneider et al., 2012). The Antarctic Peninsula, in particular, is warming at a rate 5 times faster than other regions (Vaughan et al., 2003; IPCC, 2013). The Antarctic climate system can be linked to aerosol particles by complex feedback processes that involve aerosol-cloud interactions. Also, because there are less anthropogenic emission sources in Antarctica, it is a suitable place to study the formation and growth processes of natural aerosol particles. For these reasons, monitoring the physical properties of aerosol parti- 
cles in Antarctica, such as total particle concentration, size distribution, and concentration of black carbon and activated $\mathrm{CCN}$, is necessary.

Over time aerosol particles measurements have been conducted at various research stations in Antarctica, notably Aboa (Koponen et al., 2003; Virkkula et al., 2007; Kyrö et al., 2013), Amundsen-Scott (Arimoto et al., 2004; Park et al., 2004), Concordia (Järvinen et al., 2013), Halley (Rankin and Wolff, 2003; Roscoe et al., 2015), Kohnen (Weller and Wagenbach, 2007; Hara et al., 2010), Maitri (Pant et al., 2011), Mawson (Gras, 1993), McMurdo (Hansen et al., 2001; Mazzera et al., 2001), Neumayer (Weller et al., 2015), Syowa (Ito, 1985; Hara et al., 2011b), and Troll (Fiebig et al., 2014). Antarctic aerosol particles have been investigated regarding their size distribution (Koponen et al., 2003; Belosi et al., 2012), optical properties (Shaw, 1980; Tomasi et al., 2007; Weller and Lampert, 2008), chemical composition (Virkkula et al., 2006; Weller and Wagenbach, 2007; Asmi et al., 2010; Hara et al., 2011a), and mass concentration (Mazzera et al., 2001; Mishra et al., 2004). Other studies have also focused on aerosol transport in the upper atmosphere (Hara et al., 2011b) and new particle formation (Järvinen et al., 2013; Kyrö et al., 2013; Weller et al., 2015). Although various studies have been performed in Antarctica, research on the seasonal variations of $\mathrm{CN}, \mathrm{CCN}$, and the size distribution of aerosol particles has not been considered in the Antarctic Peninsula. Furthermore, studies based on longterm observations are rare. Multi-year observations involving an analysis of the physical characteristics of $\mathrm{CCN}$ are conducted for the first time in this study.

The continuously monitored physical properties of aerosol particles at the Korean Antarctic station (King Sejong Station) from March 2009 to February 2015 are used as the basis for this study. Measurements of the aerosol size distribution and concentration of the total aerosol number, black carbon (BC), and $\mathrm{CCN}$ were conducted using various instruments. The main aim is to determine the seasonal variation in the physical properties of aerosol particles in the Antarctic Peninsula. Also, the physical characteristics of aerosol particles that originate from the ocean and continent of the Antarctic region are also investigated using air mass backtrajectory analysis.

\section{Methods}

\subsection{Sampling site and instrumentation}

Continuous observation of the physical properties of aerosol particles was carried out between March 2009 and February 2015 at King Sejong Station $\left(62.22^{\circ} \mathrm{S}, 58.78^{\circ} \mathrm{W}\right)$ in the Antarctic Peninsula. Detailed information for the sampling site is provided by Choi et al. (2008). In brief, King Sejong Station is located on the Barton Peninsula of King George Island, which has a population density higher than other re-

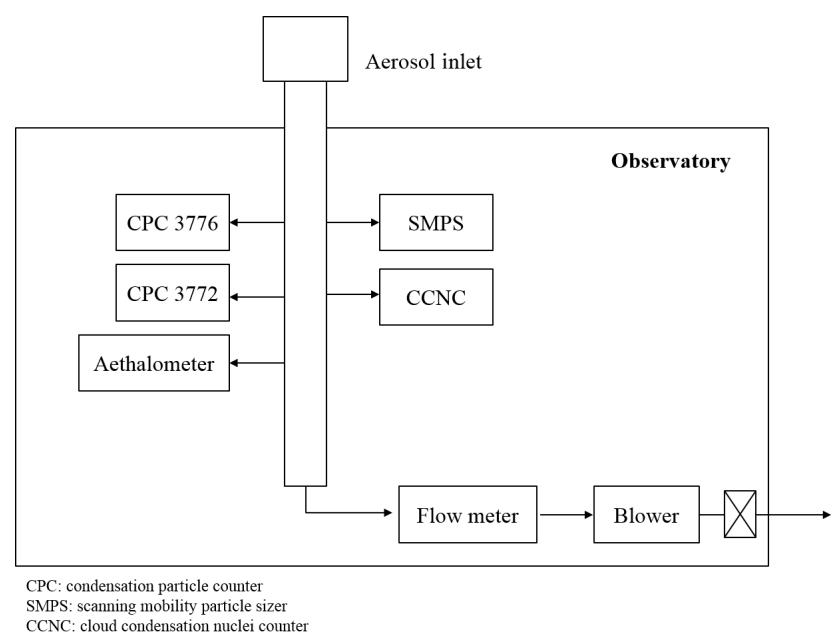

Figure 1. A schematic diagram for the observation methods used in this study.

gions in Antarctica due to the research activities conducted on eight permanent on-site stations. The observatory is located approximately $400 \mathrm{~m}$ southwest of the main buildings and includes a power generator and crematory. Thus, the northeastern direction $\left(355-55^{\circ}\right)$ is designated as a local pollution sector because of emissions from the power generator and crematory. Data collected from this sector as well as $\mathrm{BC}$ data with concentrations higher than $100 \mathrm{ng} \mathrm{m}^{-3}$ are discarded to improve the data quality of this study. Moreover, to ensure the reliability of measurements, only validated data that spanned at least $50 \%$ of one day were used for the analysis. In this study, the physical characteristics of aerosol particles collected between March 2009 and February 2015 are analysed.

The physical characteristics of aerosol particles were continuously observed with various instruments including two condensation particle counters (CPCs), an Aethalometer, a cloud condensation nuclei counter (CCNC), and a scanning mobility particle sizer (SMPS). These observation methods are shown in Fig. 1.

Based on Global Atmosphere Watch (GAW) aerosol measurement guidelines and recommendations, a cylindrical stainless common sample inlet was installed. The common inlet was placed on the roof of the observatory (Fig. 1). The diameter and length of the inlet were 0.1 and $5.2 \mathrm{~m}$, respectively. In order to understand flow condition in the common inlet, the Reynolds number was calculated. We used mean values of air temperature and pressure measured over the period from March 2009 to February 2015. The mean values of temperature and pressure were $-2.4{ }^{\circ} \mathrm{C}$ and $98.8 \mathrm{kPa}$, respectively. The total flow rate of the sampled air was maintained as $150 \mathrm{~L} \mathrm{~min}^{-1}$. The Reynolds number in the common inlet was 2388, which represents a laminar-turbulent transition flow $(2000<R e<4000)$. For sampling, a short L-bend stainless steel tube was placed at the centre of the common 
inlet. Sampling instruments were connected to the inlet using conductive tubing to minimize particle losses. The diameter and length of the conductive tubing connecting the stack with the sampling devices are $3 / 8$ in. and $0.6 \mathrm{~m}$, respectively. To maintain ambient conditions, drying was not conducted during sampling. The total counting efficiency of the sampling equipment was estimated to be 0.92 for $2.5 \mathrm{~nm}$ particles, and 1 for particles larger than $10 \mathrm{~nm}$, respectively, at the common inlet (Hinds, 1999; Baron and Willeke, 2011). All sampling lines, expect for the common inlet, were connected with conductive tubing to minimize particle losses.

The total particle number concentration was examined with two CPCs: a TSI model 3776 that measures particles greater than $2.5 \mathrm{~nm}$ in diameter, and a TSI model 3772 that measures particles larger than $10 \mathrm{~nm}$. Sample aerosol flow rates for CPC 3776 and CPC 3772 were 1.5 and $1.0 \mathrm{~L} \mathrm{~min}^{-1}$, respectively.

An Aethalometer (Magee Scientific, AE16) was used to measure the concentration of light-absorbing particles for $880 \mathrm{~nm}$ wavelengths. The flow rate of the sample was constant at $5.0 \mathrm{~L} \mathrm{~min}^{-1}$. The main purpose of measuring the $\mathrm{BC}$ concentration was to investigate the long-range transport of aerosol particles and assess the impact of local pollution.

To measure the CCN concentration, a CCNC (DMT CCN100) was used for five different supersaturation (SS) ratios $(0.2,0.4,0.6,0.8$, and $1.0 \%)$ and a total flow rate of $0.5 \mathrm{~L} \mathrm{~min}^{-1}$. The CCN concentration was determined by exposing aerosol particles at supersaturated conditions and then counting the number of activated droplets with a detector. The sampling duration was set at $5 \mathrm{~min}$ for each SS value (except for $0.2 \% \mathrm{SS}$ ) before it was changed to the next value. For $0.2 \% \mathrm{SS}$, the CCN concentration was measured for 10 min because the additional time was required to achieve stability after conducting measurements at $1 \% \mathrm{SS}$.

Aerosol size distributions were continuously measured with a SMPS, which comprises a differential mobility analyser (DMA; HCT Inc., LDMA 4210), a CPC (TSI 3772), a control unit, an aerosol neutralizer (soft X-ray), and a data logging system. The length, inner diameter, and outer diameter of the DMA were $44.42,0.953$, and $1.905 \mathrm{~cm}$, respectively. The resolution of the scanning time was set to $120 \mathrm{~s}$ for mobility particle diameters between 0.01 and $0.30 \mu \mathrm{m}$. A closed sheath-air loop with a diaphragm pump in the control unit was used to maintain the sheath flow of the DMA. The flow rate of sheath air of the DMA was $10 \mathrm{~L} \mathrm{~min}^{-1}$. The ratio of aerosol flow to sheath flow of the DMA was $1: 10$.

Also, meteorological parameters including temperature, relative humidity (RH), wind speed (WS), wind direction (WD), pressure, and UV and solar radiation were also continuously monitored over the entire observation period.

\subsection{Back-trajectory analysis}

To relate the physical properties of aerosol particles to their source areas for the sampling period, an air mass back-

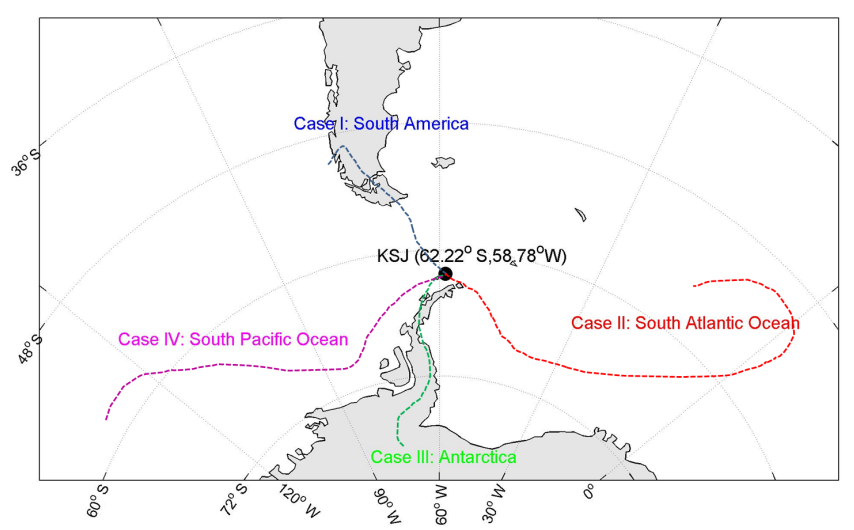

Figure 2. Map of the sampling site $\left(62.22^{\circ} \mathrm{S}, 58.78^{\circ} \mathrm{W}\right.$; black circle) and classification of the four cases according to the origin and pathway of the air masses. Dot lines represent example of back trajectories according to cases.

trajectory analysis was conducted using a Hybrid SingleParticle Lagrangian Integrated Trajectory (HYSPLIT) model (Stein et al., 2015) (http://www.arl.noaa.gov/HYSPLIT.php). For every $6 \mathrm{~h}$ period, $120 \mathrm{~h}$ air mass back trajectories were analysed, ending at heights of 100,500 , and $1500 \mathrm{~m}$ above ground level at the sampling site. Results for the origin and pathway of the air mass that were similar for at least $12 \mathrm{~h}$ for the three different heights were used in the present analysis. The air masses were then classified into four groups according to their origin and pathway, including two continental regions (South America and Antarctica) and two oceanic areas (South Atlantic and South Pacific Ocean), as shown in Fig. 2.

\section{Results and discussion}

\subsection{Meteorological conditions}

Figure 3 depicts the monthly variation in meteorological parameters measured from an automatic weather system (AWS) over the entire observation period. The temperature varied between -19.5 and $+5.8^{\circ} \mathrm{C}$, with a mean of $-2.4 \pm 2.1^{\circ} \mathrm{C}$ and relative humidity (RH) was between 60 and $100 \%$, with a mean of $87.9 \pm 3.3 \%$. As mentioned previous studies (Kwon and Lee, 2002; Mishra et al., 2004), the observation site was relatively humid and warm compared to inland Antarctic stations due to marine environment. The solar radiation varied from 2.3 to $375.4 \mathrm{~W} \mathrm{~m}^{-2}$, with a mean of $81.2 \pm 38.9 \mathrm{~W} \mathrm{~m}^{-2}$. No clear annual trends for temperature were observed during the 6-year period due to a relatively short observation period. In this paper, an analysis of the correlation between temperature (or solar radiation) and the $\mathrm{CN}$ concentration is the focus. 

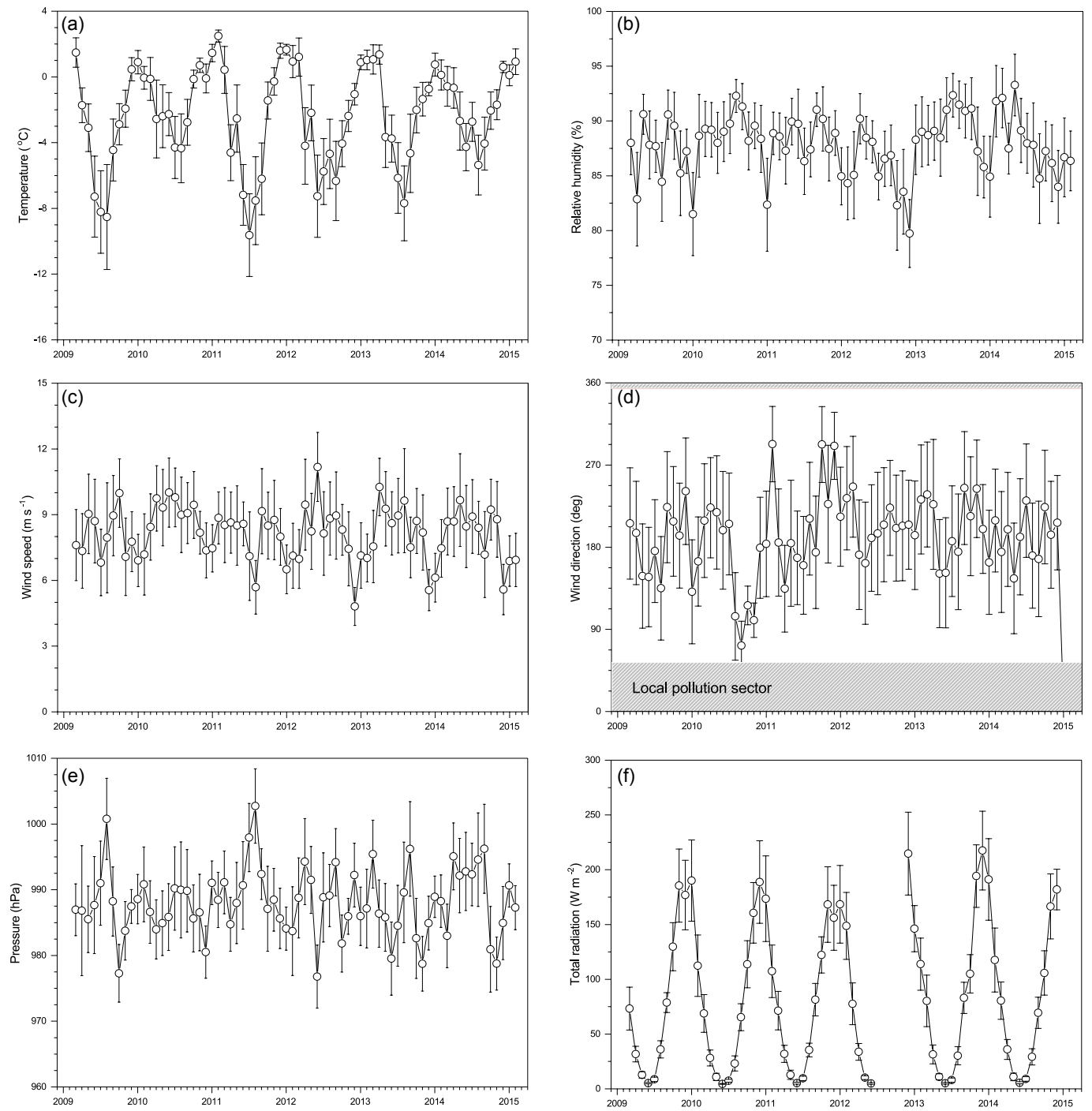

Figure 3. Monthly mean variation in (a) temperature, (b) relative humidity, (c) wind speed, (d) wind direction, (e) air pressure, and (f) solar radiation over the period from March 2009 to February 2015. The shaded area in panel (d) represents the wind direction for the local pollution sector.

\subsection{Seasonality in the physical characteristics of aerosol particles}

\subsubsection{Total particle number concentrations}

Figure 4 shows the monthly mean particle number $(\mathrm{CN})$ concentration measured with two types of instruments (TSI CPC 3776 and 3772) over the period between March 2009 and February 2015. All seasons mentioned in this study are austral seasons. As can be seen in Fig. 4, there is a clear seasonal cycle for $\mathrm{CN}$ concentration, which is highest in the summer (December to February, DJF) and lowest in the winter (June to August, JJA). The maximum concentration of particles larger than $2.5 \mathrm{~nm}\left(\mathrm{CN}_{2.5}\right)$ and larger than $10 \mathrm{~nm}\left(\mathrm{CN}_{10}\right)$ was approximately $2000 \mathrm{~cm}^{-3}$ in De- cember 2012 and about $800 \mathrm{~cm}^{-3}$ in December 2009. The minimum values of $\mathrm{CN}_{2.5}$ and $\mathrm{CN}_{10}$ concentration were approximately 110 and $90 \mathrm{~cm}^{-3}$, both in August 2013, respectively. These results are in agreement with previous studies from other Antarctic stations (Jaenicke et al., 1992; Gras, 1993; Virkkula et al., 2009; Weller et al., 2011). For instance, Virkkula et al. (2009) reported long-term daily average CN concentrations over the period from November 2003 to January 2007 from observation at Aboa, the Finnish Antarctic research station in coastal region of Antarctica. The maximum monthly average $\mathrm{CN}$ concentrations were measured in February and the minimum in July, which is the darkest period of the year. The cause of the clear seasonal cycle of $\mathrm{CN}$ concentrations may be attributed to the formation of aerosol particles. High $\mathrm{CN}_{2.5}$ concentrations during the austral sum- 


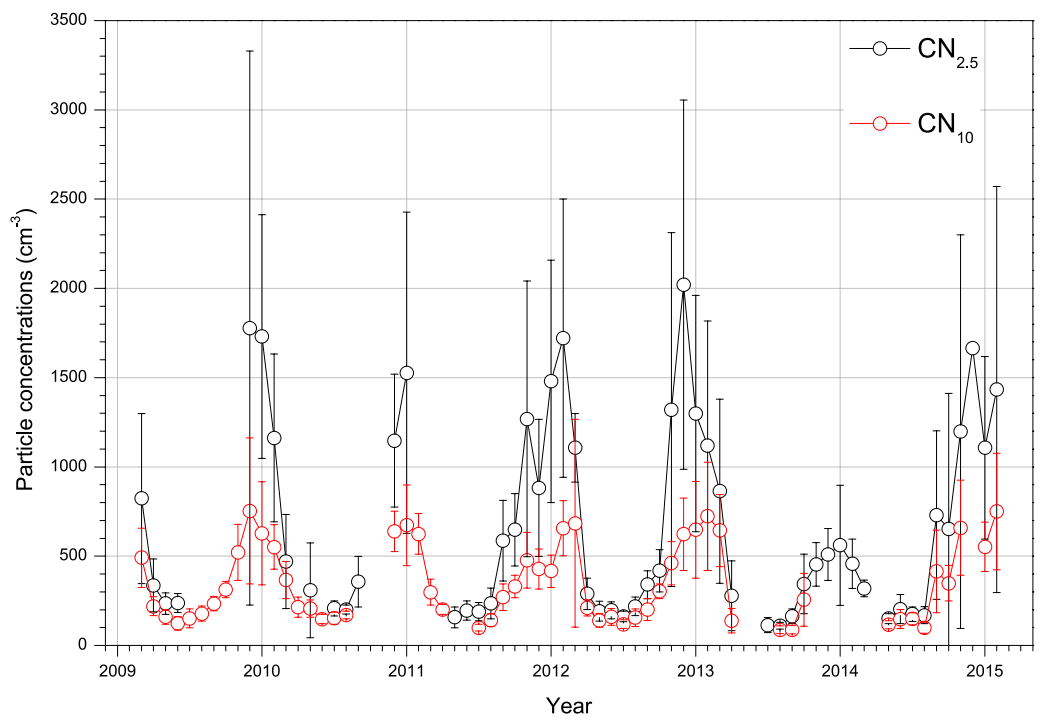

Figure 4. Monthly variations of mean $\mathrm{CN}_{2.5}$ (black open circle) and $\mathrm{CN}_{10}$ (red open circle) concentrations with a standard deviation from March 2009 to February 2015. The error bars represent the standard deviation of the measurements from the mean value.

mer season (DJF) should be related primarily to non-sea-salt sulfate and methanesulfonate (MSA) derived from the oxidation of dimethyl sulfide (DMS) produced by phytoplankton (Fattori et al., 2005; Weller et al., 2011). The DMS concentration increases sharply when biological activity was enhanced due to increasing temperatures and solar radiation (Virkkula et al., 2009). Since the sampling site for this study was in the Antarctic Peninsula, the biological activity of the ocean was considered as an important factor for the formation and growth of the aerosol particles. Higher differences in concentration occur in summer rather than winter for $\mathrm{CN}_{2.5}$ and $\mathrm{CN}_{10}$ concentration correlated with a higher biological activity in summer than winter, as well as solar radiation and temperature. Therefore, it can be supposed that trends of differences are related to secondary aerosol formation caused by biological activity. To better understand the effect of temperature and solar radiation intensity on the $\mathrm{CN}_{2.5}$ concentration, the relationship between the monthly mean $\mathrm{CN}_{2.5}$ concentration and solar radiation intensity and the monthly mean $\mathrm{CN}_{2.5}$ concentration and temperature was compared. The correlation coefficient between $\mathrm{CN}_{2.5}$ and the solar radiation intensity (open circle; $R^{2}=0.621$ ) was slightly higher than for the mean $\mathrm{CN}_{2.5}$ concentration and temperature (open triangle; $\left.R^{2}=0.419\right)$, as shown in Fig. 5. These results suggest that the $\mathrm{CN}_{2.5}$ concentration may be more closely coupled with solar radiation intensity than temperature.

Unique results for the $\mathrm{CN}_{2.5}$ concentration were observed as shown in Fig. 4. The $\mathrm{CN}_{2.5}$ concentrations in the summer of 2013-2014 were much lower than other years. Unfortunately, the reason for the lower $\mathrm{CN}_{2.5}$ concentration cannot be explained by the solar radiation intensity or temperature as there was not any distinctive variation in these values compared with other years. A possible reason is the type of air mass reached the sampling site. Although the air mass that originated in the South Pacific Ocean (Case IV: of the descriptions in Sect. 3.3) was dominant in summer, based on the air mass back-trajectory analysis explained in Sect. 2.2, the frequency of the air mass from the South Atlantic Ocean (Case II) in the summer of 2013-2014 was higher than other years and the frequency of air mass originating from Case IV was lower than other years. Unfortunately, neither $\mathrm{CN}_{10}$ nor SMPS data are available for the austral summer season of 2013-2014 because of mechanical failures. Thus, it is not possible to directly explain the low concentration for $\mathrm{CN}_{2.5}$ in this season regarding the potential effects on the air mass characteristics and the concentration of particles sized between 2.5 and $10 \mathrm{~nm}$. Nevertheless, it is likely that an increased frequency of air mass originating from the South Atlantic Ocean (Case II) might have resulted in a lower $\mathrm{CN}_{2.5}$ concentration in the austral summer season of 2013-2014. These CN concentration is comparable with results from Aboa Station, which is located in the coastal area of Antarctica and is mainly affected by South Atlantic air masses (Virkkula et al., 2009). These results showed a daily CN concentration from December 2003 to January 2007. Although there was a variation in the $\mathrm{CN}$ concentration from year to year, the daily $\mathrm{CN}$ concentration during the austral summer was $\sim 600 \mathrm{~cm}^{-3}$.

A more detailed comparison of the monthly trends for the $\mathrm{CN}_{2.5}$ and $\mathrm{CN}_{10}$ concentration is presented in Fig. 6. The monthly mean $\mathrm{CN}$ concentration increased from September to February during the austral spring and summer periods (Bigg et al., 1984; Jaenicke et al., 1992; Gras, 1993). The CN concentration sharply decreased from March and remained stable from April to August. In particular, the $\mathrm{CN}_{2.5}$ concentrations during the summer period increased sharply com- 


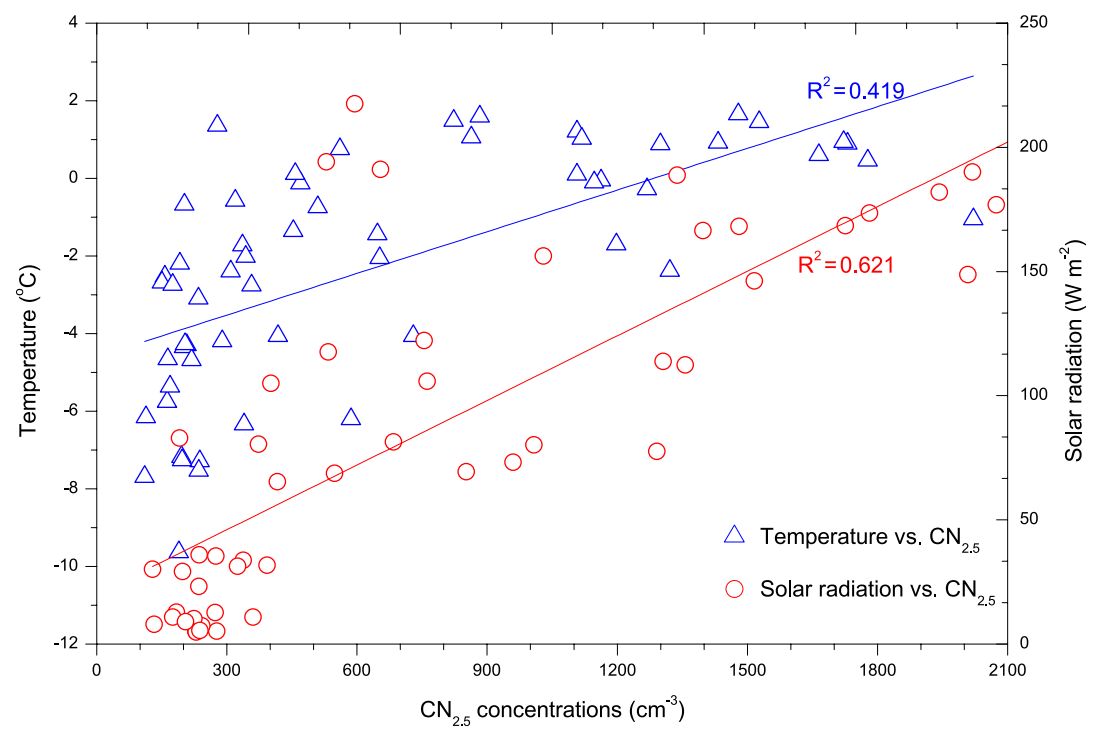

Figure 5. Scatterplot diagram of monthly mean $\mathrm{CN}_{2.5}$ concentrations and monthly mean temperature (blue open triangle) or monthly mean solar radiation intensity (red open circle). Blue and red solid lines are regression lines.

pared to the $\mathrm{CN}_{10}$ concentration. This increase was probably due to new particle formation. High solar radiation and temperature, and low RH values during the summer are conducive to new particle formation (Hamed et al., 2007).

\subsubsection{Cloud condensation nuclei $(\mathrm{CCN})$ concentrations}

Figure $7 \mathrm{a}$ shows the monthly mean $\mathrm{CCN}$ concentration at a SS value of $0.4 \%$ over the period from March 2009 to February 2015. There is a large gap in data from July 2011 to December 2013 due to a faulty CCN counter. Anttila et al. (2012) measured cloud droplet number concentration (CDNC) and CCN concentration for five SS values $(0.2,0.4$, 0.6, 0.8, and $1.0 \%$ ) during the third Palls Cloud Experiment (PaCE-3). These results showed a correlation between the $\mathrm{CDNC}$ and $\mathrm{CCN}$ concentration for each supersaturation. The relationship between the $\mathrm{CDNC}$ and $\mathrm{CCN}$ concentration at a SS value of $0.4 \%$ was approximately linear. Furthermore, $\mathrm{CCN}$ concentration were lower than the $\mathrm{CDNC}$, when the SS value was lower than $0.4 \%$, and higher than the CDNC, when the CCN concentration was above $0.4 \%$. Based on these results, supersaturation of $0.4 \%$ was chosen to investigate seasonal variation in the CCN. Monthly variation in the $\mathrm{CCN}$ concentration was found, with a maximum value observed during the summer period (DJF) and a minimum concentration observed during winter periods (JJA). The monthly mean CCN concentration ranged from $20.63 \mathrm{~cm}^{-3}$ in July 2009 to $227.52 \mathrm{~cm}^{-3}$ in January 2014, with a mean of $112.80 \pm 39.05 \mathrm{~cm}^{-3}$. Figure $7 \mathrm{~b}$ also shows seasonality for the CCN concentration at the SS value of $0.4 \%$. The $\mathrm{CCN}$ concentration gradually decreased from February and remained consistently low during the winter, while the $\mathrm{CCN}$ concentration from September increased sharply, as shown in Fig. 7b. The maximum CCN concentration in January was $199.89 \pm 37.07 \mathrm{~cm}^{-3}$ and the minimum CCN concentration in August was $42.13 \pm 14.51 \mathrm{~cm}^{-3}$. This clear seasonality for the CCN concentration follows the seasonal variation in the $\mathrm{CN}$ concentration. As shown in Fig. 6 , the $\mathrm{CN}_{10}$ concentration as well as $\mathrm{CN}_{2.5}$ concentration increased during summer. In addition, the aerosol size distribution measured by the SMPS showed that the concentration for accumulation-mode particles in the range of 100 and $300 \mathrm{~nm}$, as well as Aitkenmode particles during summer, increased significantly, as can be seen in Fig. 8. Accumulation-mode particles can easily act as CCN (Dusek et al., 2006); hence CCN concentrations increase during summer and decrease during winter.

In order to investigate the seasonal variation in fractions of the $\mathrm{CCN}$ concentration for each SS value for the $\mathrm{CCN}$ concentration at a SS of $1.0 \%$, the $\mathrm{CCN}$ data were examined in more detail. An analysis of the cumulative $\mathrm{CCN}$ concentrations given in terms of fractions of the $\mathrm{CCN}$ concentration measured at a SS of $1.0 \%$ was carried out. The results are shown in Fig. 9. Here, fractions of the CCN concentrations were estimated by dividing the $\mathrm{CCN}$ concentration at each SS value by the total CCN concentration at a SS of $1.0 \%$. Although a clear seasonal trend for $\mathrm{CCN}$ concentration with a maximum during the summer and a minimum during the winter was presented, the fraction of $\mathrm{CCN}$ concentration at a SS value of $0.2 \%$ for the activated CCN concentration showed a different pattern with a maximum value in July and a minimum value in December, as shown in Fig. 9. The numbers at the top of Fig. 9 represent the mean CCN concentration at a SS values of $1.0 \%$. The fraction of particles activated to $\mathrm{CCN}$ at a SS value of $0.2 \%$ during summer and winter was $0.49 \pm 0.07$ and $0.62 \pm 0.06$, respectively. The frac- 

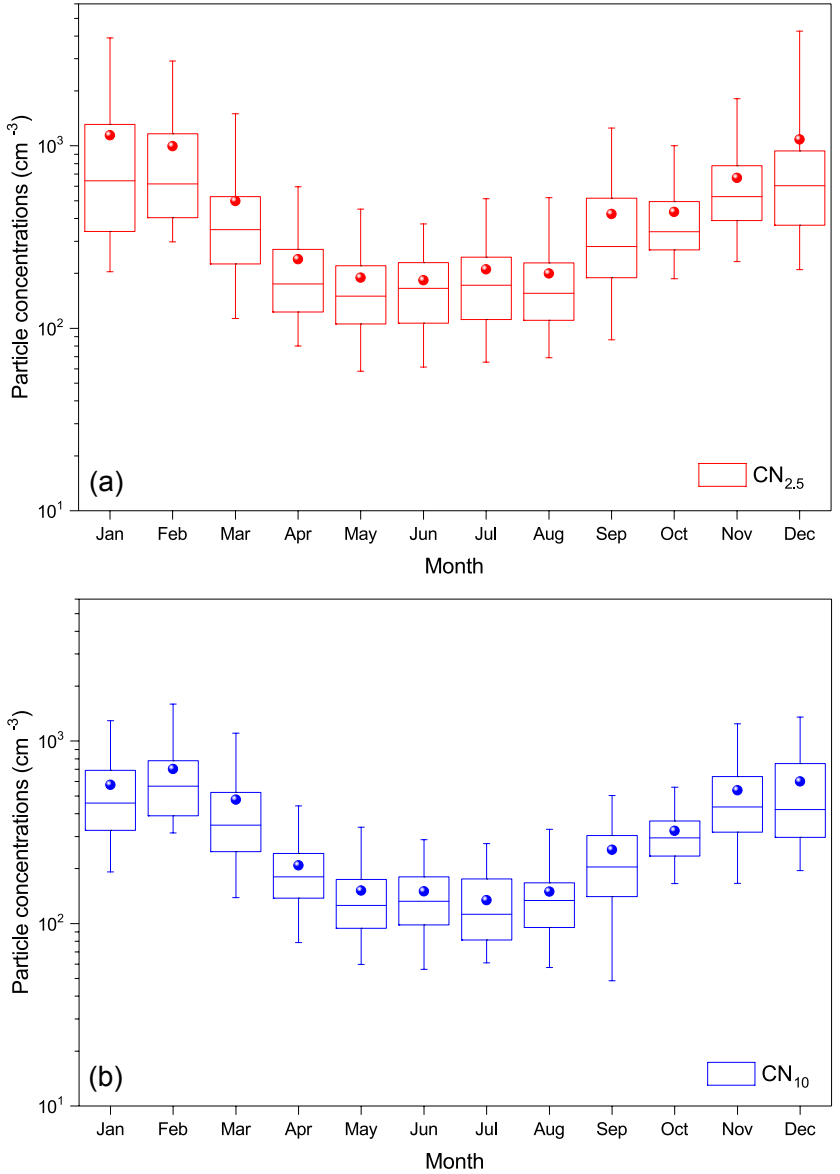

Figure 6. Box plots of seasonality of (a) $\mathrm{CN}_{2.5}$ and (b) $\mathrm{CN}_{10}$ concentrations. Lines in the middle of the boxes indicate sample medians (mean value is closed circle), lower and upper lines of the boxes are the 25th and 75th percentiles, and whiskers indicate the 5th and 95th percentiles.

tion at a SS value of $0.2 \%$ during winter (JJA) was similar to that $(\sim 0.52)$ measured at Mace Head Station, which is a representative site of a marine environment (Paramonov et al., 2015).

Seasonal variation in the mean activation ratio of the CCN concentration at a SS of $0.4 \%$ to the $\mathrm{CN}$ concentration measured by the two CPCs (TSI 3776 and 3772) are shown in Fig. 10. The mean value of the activation ratios of $\mathrm{CCN} / \mathrm{CN}_{2.5}$ and $\mathrm{CCN} / \mathrm{CN}_{10}$ were $0.33 \pm 0.10$ and $0.40 \pm 0.08$, respectively. Although clear changes were observed in the monthly variation for the $\mathrm{CN}$ and $\mathrm{CCN}$ concentrations as shown in Figs. 6 and 7b, it was seen that the activation ratio $\left(\mathrm{CCN} / \mathrm{CN}_{10}\right)$ was similar regardless of seasonality. The reason that no clear change is observed in the activation ratio at King Sejong Station might be the variation in the concentration of accumulation-mode particles, as can be seen in Fig. 8. The lower activation ratio in September and November is because of the size and chemical properties of the aerosol particles. Both the size and chemical
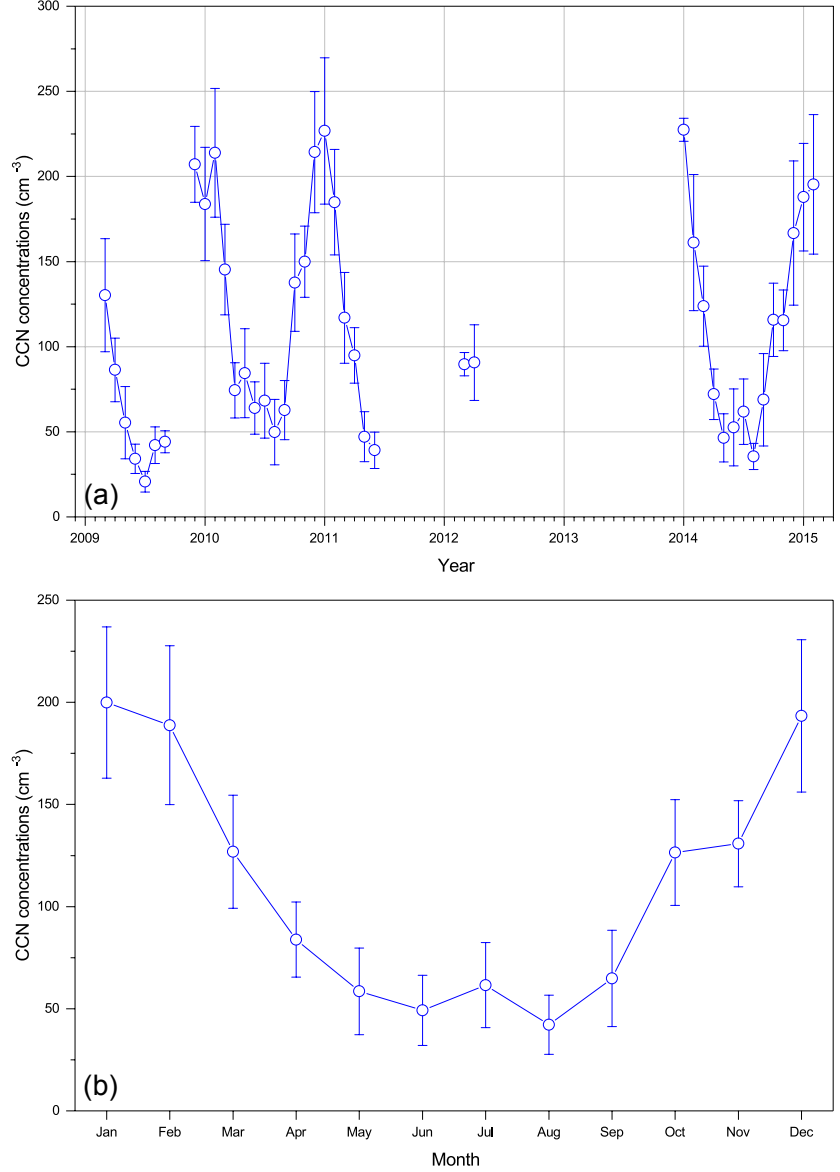

Figure 7. (a) Monthly mean CCN concentrations at the SS of $0.4 \%$ with a standard deviation from March 2009 to February 2015. (b) Seasonal variation in mean CCN concentrations at the SS of $0.4 \%$ with a standard deviation.

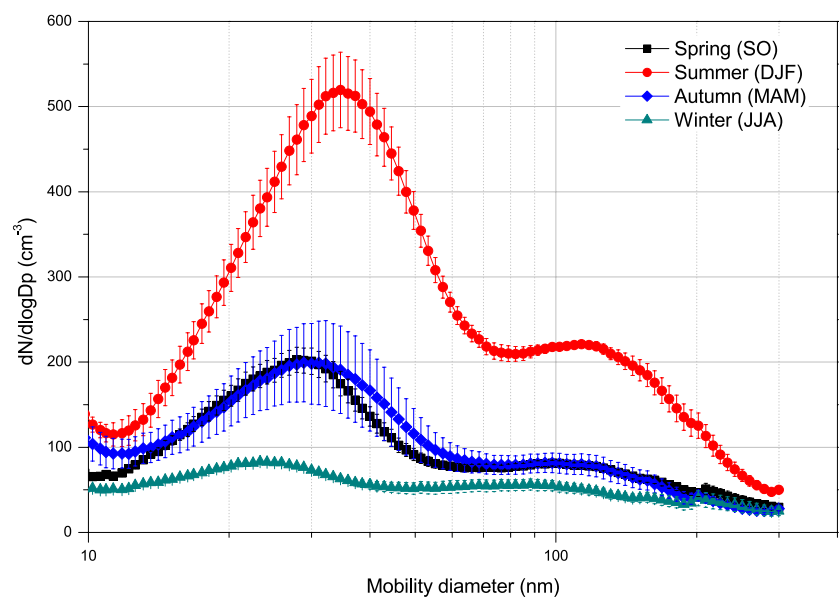

Figure 8. Seasonal mean aerosol size distribution measured by the SMPS at the King Sejong research station over the period from March 2009 to February 2015. The error bars represent the standard deviation of the measurements from the mean value. 


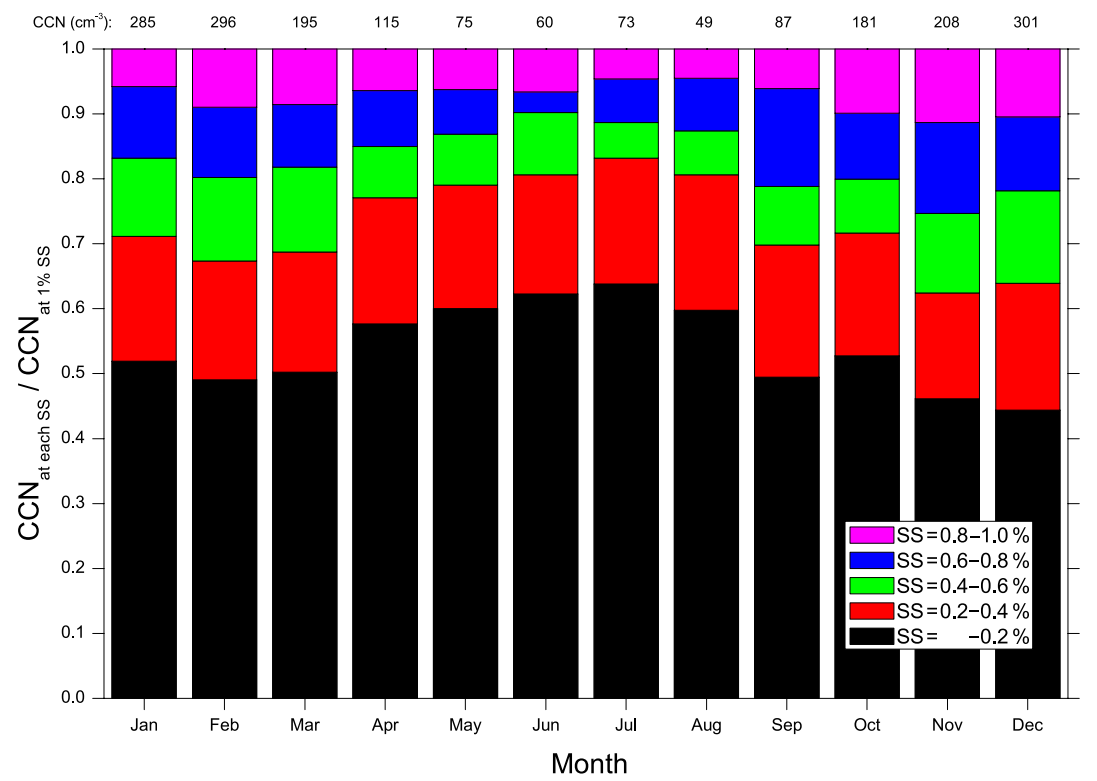

Figure 9. Monthly mean cumulative $\mathrm{CCN}$ concentrations shown as fractions of the CCN concentration at the SS of $1.0 \%$. Colours indicate the SS bins. The number at the top of figure represents monthly mean CCN concentrations at the SS values of $1.0 \%$.

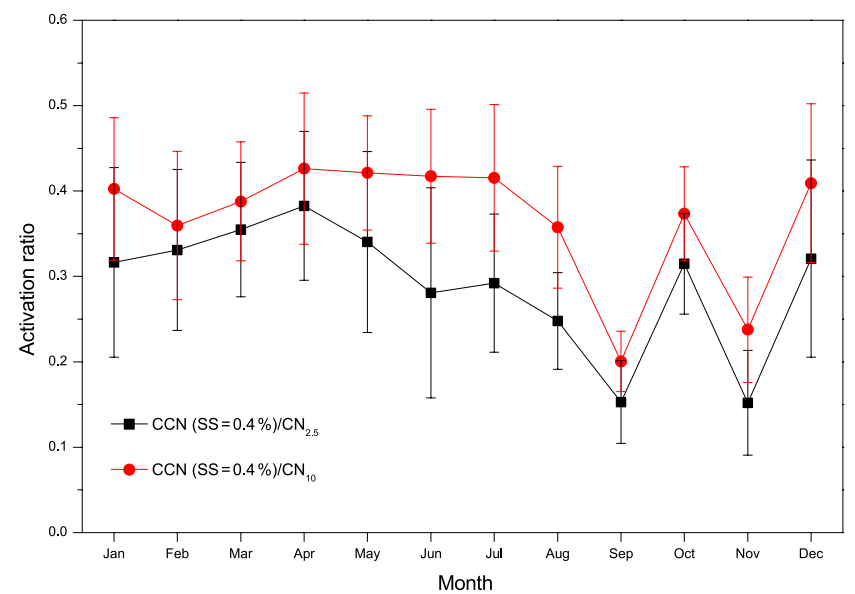

Figure 10. Comparison of the seasonal mean variation in the activation ratio between measurements (CPC 3776 and CPC 3772) by two CPCs. The error bars represent the standard deviation of the measurements from the mean value.

composition of the aerosol particles can have a large impact on the activation ratio (Dusek et al., 2006; Leena et al., 2016). The concentration of Aitken-mode aerosol particles increased sharply compared to the concentration in August. Thus, the activation ratio decreased dramatically. Unfortunately, the aerosol size distribution could not be confirmed because the aerosol size distribution data for November were not reliable due to malfunctioning instruments.

The CCN concentrations for different SS values can be represented by the power-law function, defined by Twomey (1959):
$N_{\mathrm{CCN}}=C \cdot(\mathrm{SS})^{k_{T}}$,

where $N_{\mathrm{CCN}}$ is the concentration of $\mathrm{CCN}$ at given a supersaturation value (SS) and $C$ and $k_{T}$ are coefficient constants estimated from CCN spectra. The correlation coefficient between the measured CCN concentration at a SS of $0.4 \%$ and the fitted values of the power-law function was 0.978 . The values of $\mathrm{C}$ varied from 6.35 to $837.24 \mathrm{~cm}^{-3}$, with a mean of $171.48 \pm 62.00 \mathrm{~cm}^{-3}$. The daily mean $k_{T}$ values vary between 0.07 and 2.19 , with a mean of $0.41 \pm 0.10$. The monthly variations of $k_{T}$ and $C$ values are summarized in Fig. 11. A comparison with $\mathrm{CCN}$ concentrations indicated that the values for $k_{T}$ during the austral winter (June) were also the lowest $(0.29 \pm 0.06)$, while during summer (December) they were highest $(0.55 \pm 0.13)$. Based on this result, aerosol particles activated to $\mathrm{CCN}$ during summer are expected to be more sensitive to SS changes than aerosol particles activated during winter.

It is useful to infer the hygroscopic properties of aerosol particles with the hygroscopicity parameter, $\kappa . \kappa$ values varied from 0 for insoluble particles to larger than 1 for watersoluble salt particles (Petters and Kreidenweis, 2007). $\kappa$ values are defined as

$\kappa=\frac{4 A^{3}}{27 D_{\mathrm{act}}^{3} \ln ^{2} \mathrm{SS}} \quad A=\frac{4 \sigma_{\mathrm{w}} M_{\mathrm{w}}}{R T \rho_{\mathrm{w}}}$,

where $\sigma_{\mathrm{w}}$ is surface tension of water, $M_{\mathrm{w}}$ is the molecular weight of water, $R$ is the universal gas constant, $T$ is the temperature, and $\rho_{\mathrm{w}}$ is the density of water. SS is the supersaturation applied in the CCNC. The critical diameter, $D_{\text {act }}$, 

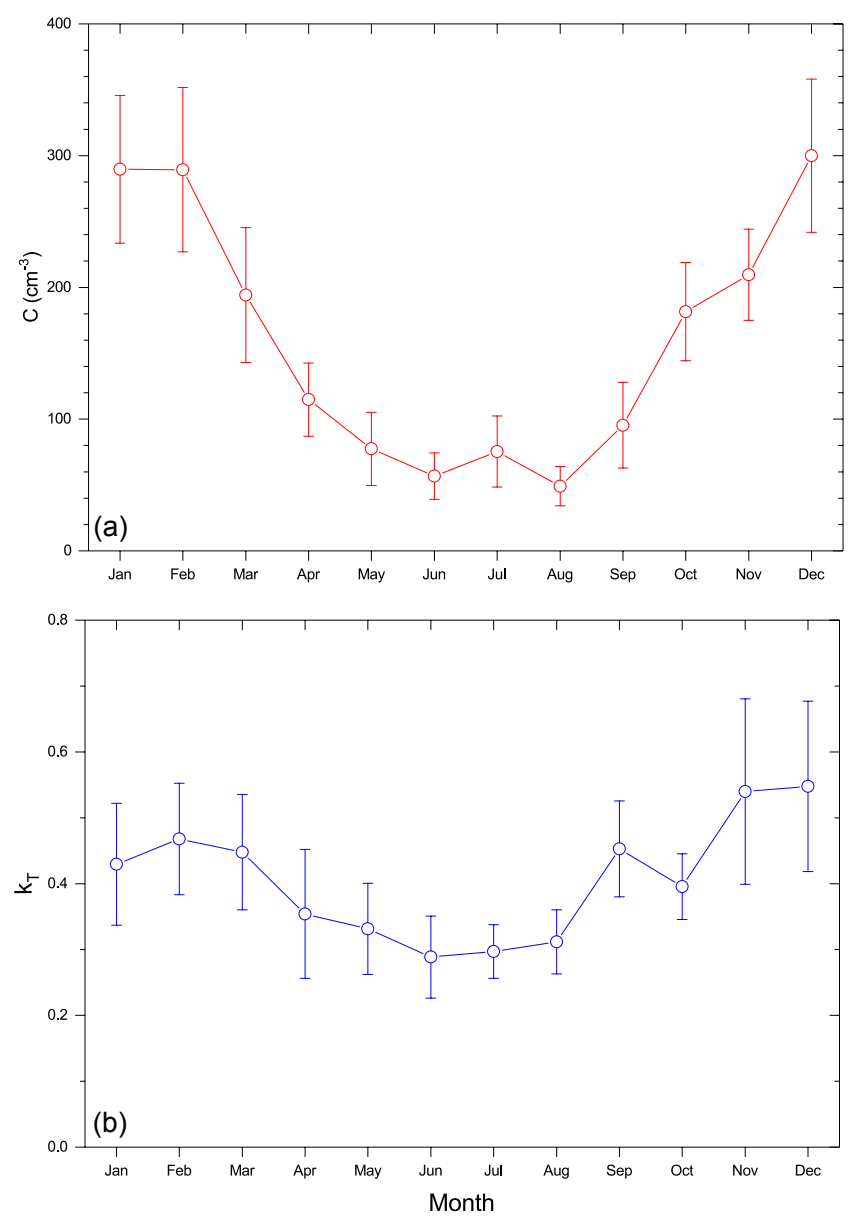

Figure 11. Seasonality of monthly mean values of (a) $C$ and (b) $k_{T}$ over the whole observation periods. The error bar represents the standard deviation of the measurements from the mean value.

was estimated following the method of Furutani et al. (2008)

$\frac{\int_{D_{0}}^{D_{\text {act }}} n(D) \mathrm{d} D}{N_{\text {tot }}}=1-\frac{\mathrm{CCN}}{\mathrm{CN}}$,

where $N_{\text {tot }}$ is total number concentrations of aerosol particles measured by SMPS. $D$ is the electric mobility diameter observed by SMPS. In this calculation, $D_{0}$ was assumed to be $10 \mathrm{~nm}$, at the beginning of the SMPS scan. The CCN / CN ratio indicates the fraction of $\mathrm{CCN}$-active aerosols of the total particle concentration. In this study, the $\kappa$ values were estimated using a monthly mean $\mathrm{CCN}$ concentration at a SS of $0.4 \%$, the monthly mean $\mathrm{CN}$ concentrations measured by the $\mathrm{CPC}$, and the monthly mean size number distribution results obtained from the SMPS data. The annual mean $\kappa$ value was calculated to be $0.15 \pm 0.05$. This value is comparable to the previous studies from the Arctic and subarctic areas. For example, Lathem et al. (2013), who measured the CCN activity in the Arctic using aircraft measurements, reported a $\kappa$ value of $0.32 \pm 0.21$. Martin et al. (2011) inferred a total $\kappa$ value of $0.33 \pm 0.13$ during a cruise observation in Longyear-

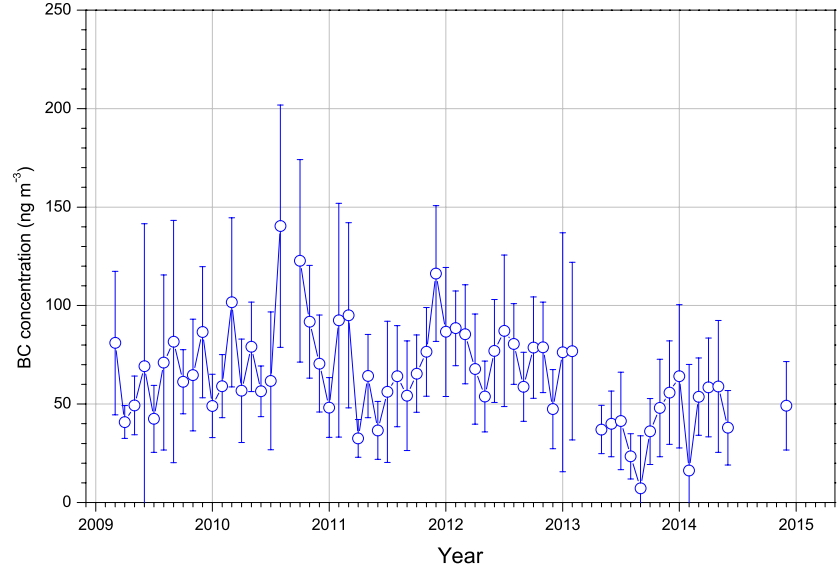

Figure 12. Monthly mean concentrations of black carbon over the period from March 2009 to February 2015. The error bars represent the standard deviation of the measurements from the mean value.

byen, Svalbard. Kammermann et al. (2010) reported $\kappa$ values that varied between 0.07 and 0.21 over an 18-day period within the Arctic Circle in Sweden. Jaatinen et al. (2014) also showed a $\kappa$ value of $0.13 \pm 0.07$ using a 13-day dataset from the subarctic area of Finland (Pallas-Sodankylä station).

\subsubsection{Black carbon (BC) concentrations}

Figure 12 shows the variation in monthly mean $\mathrm{BC}$ concentrations over the whole sampling period. To eliminate the effect of local pollution on the observations, in the present study, data of $\mathrm{BC}$ concentration higher than $100 \mathrm{ng} \mathrm{m}^{-3}$ were discarded. The daily mean $\mathrm{BC}$ concentration varied between 1.07 and $75.97 \mathrm{ng} \mathrm{m}^{-3}$, with a mean of $27.43 \pm 4.98 \mathrm{ng} \mathrm{m}^{-3}$. The BC concentration observed at King Sejong Station was higher than those at other stations in Antarctica (Bodhaine, 1995; Wolff and Cachier, 1998; Pereira et al., 2006; Weller et al., 2013). For instance, the annual mean BC concentrations at the South Pole, Halley, Neumayer, and Ferraz stations were $0.65,1.0,2.6$, and $8.3 \mathrm{ng} \mathrm{m}^{-3}$, respectively. The reason for the higher $\mathrm{BC}$ concentration might be related to location of sampling site. There are nine permanent on-site stations in the Baton Peninsula of King George Island. In particular, six stations are located within a $10 \mathrm{~km}$ radius of King Sejong Station. The presence of these stations should affect the measured $\mathrm{BC}$ concentration, causing a positive bias. Also, no clear seasonal patterns were observed in this study throughout the entire observation period. However, clear seasonal patterns were observed in previous studies at other stations in Antarctica (Wolff and Cachier, 1998; Weller et al., 2013). Wolff and Cachier (1998) showed seasonal cycles of BC measured at the Halley Station and the South Pole with an Aethalometer. They found that although $\mathrm{BC}$ concentrations varied depending on the sampling site, $\mathrm{BC}$ concentration decreased during the austral winter (JJA) and increased during the austral summer (DJF). Contrary to Pereira et al. (2006), 
Table 1. Summary of meteorology and aerosol data according to the origin and transport pathway of aerosol particles. Case I, Case II, Case III, and Case IV refer to the origin and pathway of the air masses from South America, South Atlantic Ocean, Antarctica and South Pacific Ocean, respectively.

\begin{tabular}{lrrrrr}
\hline & Overall & Case I & Case II & Case III & Case IV \\
\hline Wind speed $\left(\mathrm{m} \mathrm{s}^{-1}\right)$ & $8.4 \pm 1.8$ & $2.6 \pm 1.1$ & $6.0 \pm 1.5$ & $6.7 \pm 1.7$ & $8.6 \pm 1.8$ \\
Wind direction $\left(^{\circ}\right)$ & $237.2 \pm 55.8$ & $186.2 \pm 20.7$ & $155.9 \pm 50.3$ & $206.9 \pm 52.3$ & $242.7 \pm 55.3$ \\
BC concentrations $\left(\mathrm{ng} \mathrm{m}^{-3}\right)$ & $65.1 \pm 29.2$ & $122.2 \pm 10.6$ & $36.7 \pm 14.2$ & $65.6 \pm 30.0$ & $66.5 \pm 29.5$ \\
$\mathrm{CCN}$ concentrations $\left(\mathrm{cm}^{-3}\right)$ & $129.7 \pm 50.5$ & $212.8 \pm 50.2$ & $146.0 \pm 50.3$ & $128.9 \pm 34.9$ & $128.7 \pm 50.8$ \\
$\mathrm{CN}_{2.5}$ concentrations $\left(\mathrm{cm}^{-3}\right)$ & $737.3 \pm 849.4$ & $374.9 \pm 64.4$ & $605.3 \pm 517.6$ & $578.9 \pm 377.3$ & $751.2 \pm 877.1$ \\
$\mathrm{CN}_{10}$ concentrations $\left(\mathrm{cm}^{-3}\right)$ & $347.8 \pm 229.1$ & $358.8 \pm 61.2$ & $268.8 \pm 173.9$ & $331.9 \pm 133.0$ & $352.2 \pm 234.9$ \\
Frequency & & 3 & 113 & 118 & 2407 \\
\hline
\end{tabular}
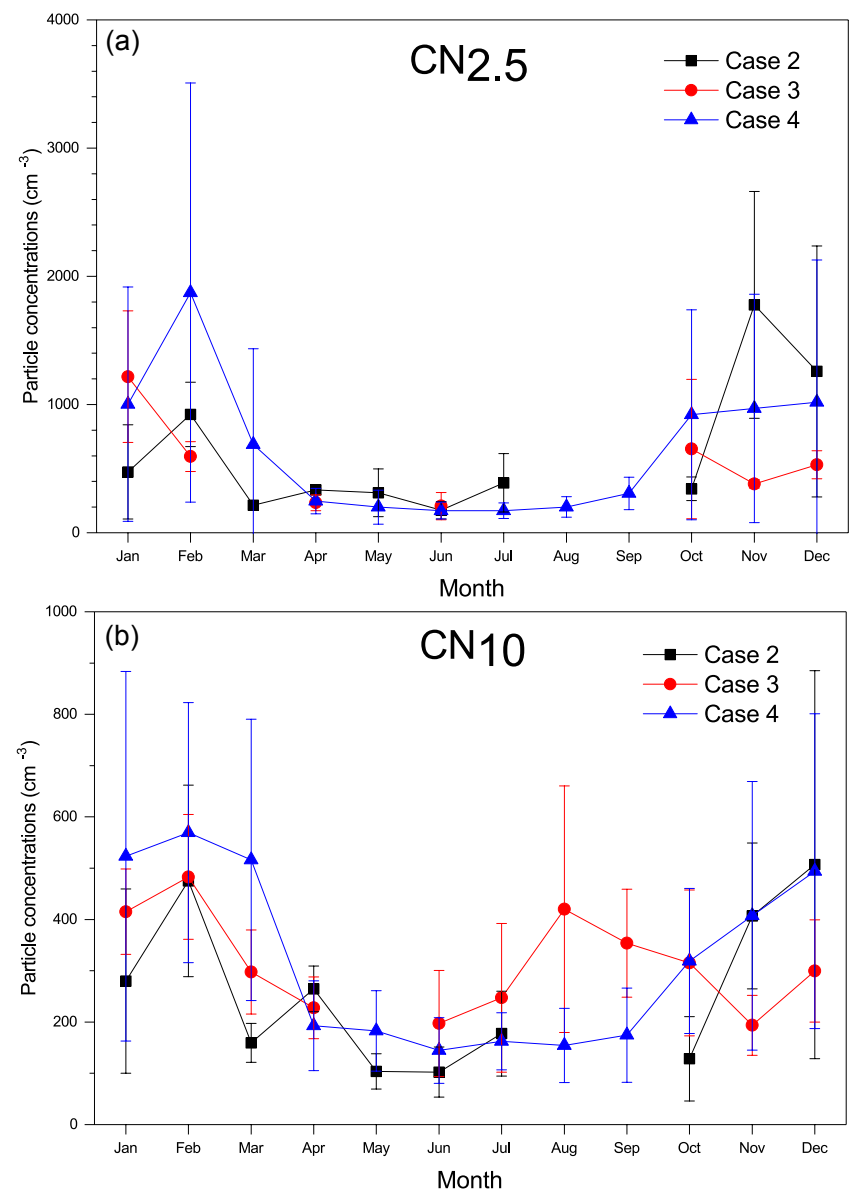

Figure 13. Seasonal variation in mean (a) $\mathrm{CN}_{2.5}$ and (b) $\mathrm{CN}_{10}$ concentrations with a standard deviation depending on the air mass origin. The error bars represent the standard deviation of the measurements from the mean value.

although BC concentration during summer increases slightly, no clear seasonal trends were observed unlike the results measured by Wolff and Cachier (1998). This suggests that the $\mathrm{BC}$ concentrations are dependent on the sampling site and the long-range transport of air mass.

\subsection{Effect of air mass trajectory on the physical properties of aerosol particles}

In this section, the effect of the origin and pathway of the air mass on the physical characteristics of the aerosol particles is presented. As mentioned earlier in Sect. 2.2, air masses are classified into four groups based on air mass back-trajectory analysis. The wind data and aerosol characteristics of the four types of air masses over the entire observation period are listed in Table 1. The very few cases of air masses originating from South America (Case I) showed the highest BC and $\mathrm{CCN}$ concentration. This may be due to anthropogenic influences at the source and the aging of aerosol particles. The $\mathrm{CN}_{10}$ concentration was similar regardless of the origin and pathway of air mass, whereas an enhancement of the $\mathrm{CN}_{2.5}$ concentration was observed when the air mass originated from the ocean (Case II and IV). This is probably due to the high biological activity in the South Atlantic and South Pacific oceans during summer (DJF). A more detailed comparison, excluding the results of Case I from the $\mathrm{CN}$ concentration based on an air mass analysis is shown in Fig. 13. It should be noted that the mean values of $\mathrm{CN}$ concentration in this analysis fall within the range of standard deviation for the mean values of each case. This is probably because of new particle formation, causing a bias, as new particle formation results in a sudden increase in aerosol concentration (Kulmala et al., 2004; Pierce and Adams, 2007). The minimum concentration of aerosol particles for $\mathrm{CN}_{2.5}$ and $\mathrm{CN}_{10}$ originate from the ocean (Case II and IV). These are observed from April to September, whereas the concentration of aerosol particles $\left(\mathrm{CN}_{2.5}\right)$ originating from the South Atlantic (Case II) and the South Pacific (Case IV) oceans are highest in November and February, respectively. It was found here that the peak month for the $\mathrm{CN}_{2.5}$ concentration had discrepancies with the air mass history. This is probably due to a difference in the chemical compounds that contribute to aerosol formation processes and/or variations in biogenic activity according to the origin and transport pathway of the air mass. To verify this, further studies on the chemical compositions of aerosol particles are necessary. For air masses 


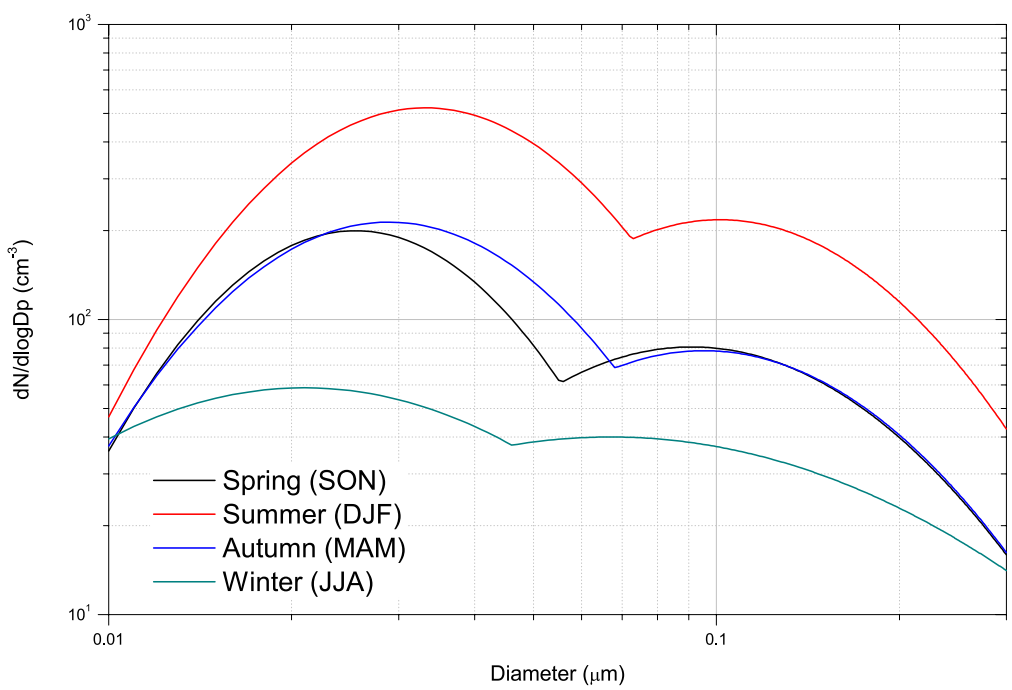

Figure 14. Seasonal log-normal fitted size distribution of aerosol particles originating from the South Pacific Ocean, ranging from 0.01 to $0.3 \mu \mathrm{m}$ (Case IV).

Table 2. Seasonal size distribution lognormal fitting parameters for the Aitken and accumulation mode of aerosol particles originating from a Case IV scenario. $N, \sigma$, and $D_{\mathrm{g}}$ refer to the number concentrations, a standard deviation, and the geometric mean diameter, respectively.

\begin{tabular}{lrrr|rrr}
\hline & \multicolumn{3}{c|}{ Aitken mode } & \multicolumn{3}{c}{ Accumulation mode } \\
\cline { 2 - 7 } & $N\left(\mathrm{~cm}^{-3}\right)$ & $\sigma$ & $D_{\mathrm{g}}(\mu \mathrm{m})$ & $N\left(\mathrm{~cm}^{-3}\right)$ & $\sigma$ & $D_{\mathrm{g}}(\mu \mathrm{m})$ \\
\hline Spring (SON) & 112.010 & 1.655 & 0.026 & 53.873 & 1.939 & 0.094 \\
Summer (DJF) & 304.359 & 1.727 & 0.034 & 140.250 & 1.823 & 0.109 \\
Autumn (MAM) & 118.643 & 1.764 & 0.028 & 50.934 & 1.901 & 0.092 \\
Winter (JJA) & 49.164 & 2.296 & 0.023 & 44.780 & 2.827 & 0.086 \\
\hline
\end{tabular}

transported from the South Pacific Ocean to King Sejong Station (Case IV), the seasonality of the aerosol size distribution was also investigated. The aerosol size distribution parameters were fitted to a log-normal distribution derived for each season. The seasonally averaged log-normal aerosol size distribution is shown in Fig. 14. The computed modal diameters along with the standard deviation and number concentrations are summarized in Table 2. It is clear that the modal diameter during summer is larger than during winter for both Aitken ( 0.034 compared to $0.023 \mu \mathrm{m}$, respectively) and accumulation modes ( 0.109 compared to $0.086 \mu \mathrm{m}$, respectively). The number concentrations for summer are also higher than those for the winter for the $(304.36 \pm 20.10 \mathrm{com}-$ pared to $49.16 \pm 3.88 \mathrm{~cm}^{-3}$, respectively) and accumulation (140.25 \pm 10.64 compared to $44.78 \pm 14.24 \mathrm{~cm}^{-3}$, respectively) modes. The enhancement of the number concentrations for the Aitken mode during summer should be linked to new particle formation over the ocean as a product of biological activity. The spring and autumn season shows intermediate values. These results are similar to those of previous laboratory and field experiments (Sellegri et al., 2006; Yoon et al., 2007). O'Dowd et al. (2004) suggested that primary forma- tion processes play a significant role in marine aerosol production in the North Atlantic Ocean. In addition, the contribution of biological organic compounds to the marine aerosol distribution might be dominant (Kim et al., 2015).

\section{Summary and conclusions}

Seasonal variations in the physical characteristics of aerosol particles at King Sejong Station $\left(62.22^{\circ} \mathrm{S}, 58.78^{\circ} \mathrm{W}\right)$ in the Antarctic Peninsula were investigated based on in situ measured aerosol data between March 2009 and February 2015. A clear seasonal variation in particle number concentration (CN) exists, with maximum concentration in the austral summer (DJF) and minimum concentration in the austral winter (JJA). The maximum $\mathrm{CN}$ concentration of particles larger than $2.5 \mathrm{~nm}\left(\mathrm{CN}_{2.5}\right)$ and $10 \mathrm{~nm}\left(\mathrm{CN}_{10}\right)$ was approximately $2000 \mathrm{~cm}^{-3}$ in December 2012 and about $800 \mathrm{~cm}^{-3}$ in December 2009 and February 2015, respectively. In particular, the $\mathrm{CN}_{2.5}$ concentration increased sharply during the summer compared to $\mathrm{CN}_{10}$ concentration, suggesting that particle formation processes are likely driven by high biological activity. 
In addition, clear seasonal trends of $\mathrm{CCN}$ concentration at a supersaturation (SS) of $0.4 \%$ were presented. The maximum mean CCN concentration of $199.89 \pm 37.07 \mathrm{~cm}^{-3}$ was measured in January and the minimum mean CCN concentration was $42.13 \pm 14.51 \mathrm{~cm}^{-3}$ in August. The activation ratio $\left(\mathrm{CCN} / \mathrm{CN}_{10}\right)$ of aerosol particles at King Sejong Station $(0.40 \pm 0.08)$ in the Antarctic Peninsula was lower than those at the Arctic area (0.52) (Lathem et al., 2013). The measured CCN spectra were approximated by fitting a power-law function relating the number of $\mathrm{CCN}$ at a given $\mathrm{SS}$ to the $\mathrm{SS}$, with fitting coefficients, $C$ and $k_{T}$ (Twomey, 1959). The values of $C$ varied between 6.35 and $837.24 \mathrm{~cm}^{-3}$, with a mean of $171.48 \pm 62.00 \mathrm{~cm}^{-3}$. The value of $k_{T}$ ranged from 0.07 to 2.19 , with a mean of $0.41 \pm 0.10$. The $k_{T}$ values during the austral summer period (DJF) were higher than those during the winter period (JJA). Furthermore, the annual mean hygroscopicity parameter, $\kappa$, was estimated as $0.15 \pm 0.05$, for a SS of $0.4 \%$.

Based on a backward trajectory analysis, air masses were classified into four groups according to their origin and pathway including two continental regions (South America and Antarctica) and two oceanic areas (South Atlantic and South Pacific Ocean). It was found that most air masses originated from the oceanic areas. The very few cases of air masses originating from the South American continent (Case I) showed the highest $\mathrm{BC}$ and $\mathrm{CCN}$ concentrations. The $\mathrm{CN}_{10}$ concentrations were analogous regardless of origin, whereas $\mathrm{CN}_{2.5}$ concentrations showed differing values. The $\mathrm{CN}_{2.5}$ concentrations that originated from oceanic areas (Case II and IV) were higher than those from continental regions (Case III). In particular, the $\mathrm{CN}_{2.5}$ concentration showed clear seasonal variations, with minimum concentrations from April to September and maximum concentrations in November from the South Atlantic Ocean (Case II) and in February from the South Pacific Ocean (Case IV). Furthermore, regarding Case IV, an analysis of aerosol size distributions in the 0.01 to $0.3 \mu \mathrm{m}$ range was performed. The modal diameters also showed seasonal variations of $0.023 \mu \mathrm{m}$ in the winter and $0.034 \mu \mathrm{m}$ in the summer for the Aitken mode and $0.086 \mu \mathrm{m}$ in the winter and $0.109 \mu \mathrm{m}$ in the summer for the accumulation mode.

Overall, this study is the first of its kind to analyse seasonal variations in physical characteristics of aerosol particles in the Antarctic Peninsula. The aerosol particle formation process is still not fully understood, and thus more studies should be necessary to determine seasonal variations in the chemical characteristics of atmospheric aerosols.

Data availability. The data analysed in this publication will be readily provided upon request to the corresponding author (yjyoon@kopri.re.kr).
Competing interests. The authors declare that they have no conflict of interest.

Acknowledgements. We would like to thank the many technicians and scientists of the overwintering crews. This work was supported by a Korea Grant from the Korean Government (MSIP) (NRF2016M1A5A1901769) (KOPRI-PN17081) and the KOPRI project (PE17010).

Edited by: Nikos Hatzianastassiou

Reviewed by: four anonymous referees

\section{References}

Anttila, T., Brus, D., Jaatinen, A., Hyvärinen, A.-P., Kivekäs, N., Romakkaniemi, S., Komppula, M., and Lihavainen, H.: Relationships between particles, cloud condensation nuclei and cloud droplet activation during the third Pallas Cloud Experiment, Atmos. Chem. Phys., 12, 11435-11450, https://doi.org/10.5194/acp-12-11435-2012, 2012.

Arimoto, R., Hogan, A., Grube, P., Davis, D., Webb, J., Schloesslin, C., Sage, S., and Raccah, F.: Major ions and radionuclides in aerosol particles from the South Pole during ISCAT-2000, Atmos. Environ., 38, 5473-5484, https://doi.org/10.1016/j.atmosenv.2004.01.049, 2004.

Asmi, E., Frey, A., Virkkula, A., Ehn, M., Manninen, H. E., Timonen, H., Tolonen-Kivimäki, O., Aurela, M., Hillamo, R., and Kulmala, M.: Hygroscopicity and chemical composition of Antarctic sub-micrometre aerosol particles and observations of new particle formation, Atmos. Chem. Phys., 10, 4253-4271, https://doi.org/10.5194/acp-10-4253-2010, 2010.

Baron, P. A. and Willeke, K.: Aerosol measurement: principles, techniques, and applications, 2nd Edn., Wiley-Interscience, New York, 2001.

Belosi, F., Contini, D., Donateo, A., Santachiara, G., and Prodi, F.: Aerosol size distribution at Nansen Ice Sheet Antarctica, Atmos. Res., 107, 42-50, https://doi.org/10.1016/j.atmosres.2011.12.007, 2012.

Bigg, E. K., Gras, J. L., and Evans, C.: Origin of Aitken particles in remote regions of the Southern Hemisphere, J. Atmos. Chem., 1, 203-214, https://doi.org/10.1007/bf00053841, 1984.

Bodhaine, B. A.: Aerosol absorption measurements at Barrow, Mauna Loa and the south pole, J. Geophys. Res., 100, 89678975, https://doi.org/10.1029/95jd00513, 1995.

Chen, J. L., Wilson, C. R., Blankenship, D., and Tapley, B. D.: Accelerated Antarctic ice loss from satellite gravity measurements, Nat. Geosci., 2, 859-862, https://doi.org/10.1038/ngeo694, 2009.

Choi, T., Lee, B. Y., Kim, S. J., Yoon, Y. J., and Lee, H. C.: Net radiation and turbulent energy exchanges over a non-glaciated coastal area on King George Island during four summer seasons, Antarct. Sci., 20, 99-111, https://doi.org/10.1017/s095410200700082x, 2008.

Dusek, U., Frank, G. P., Hildebrandt, L., Curtius, J., Schneider, J., Walter, S., Chand, D., Drewnick, F., Hings, S., Jung, D., Borrmann, S., and Andreae, M. O.: Size matters more than chem- 
istry for cloud-nucleating ability of aerosol particles, Science, 312, 1375-1378, https://doi.org/10.1126/science.1125261, 2006.

Fattori, I., Becagli, S., Bellandi, S., Castellano, E., Innocenti, M., Mannini, A., Severi, M., Vitale, V., and Udisti, R.: Chemical composition and physical features of summer aerosol at Terra Nova Bay and Dome C, Antarctica, J. Environ. Monitor., 7, 1265-1274, https://doi.org/10.1039/b507327h, 2005.

Fiebig, M., Hirdman, D., Lunder, C. R., Ogren, J. A., Solberg, S., Stohl, A., and Thompson, R. L.: Annual cycle of Antarctic baseline aerosol: controlled by photooxidationlimited aerosol formation, Atmos. Chem. Phys., 14, 3083-3093, https://doi.org/10.5194/acp-14-3083-2014, 2014.

Furutani, H., Dall'osto, M., Roberts, G. C., and Prather, K. A.: Assessment of the relative importance of atmospheric aging on CCN activity derived from field observations, Atmos. Environ., 42, 3130-3142, https://doi.org/10.1016/j.atmosenv.2007.09.024, 2008.

Gras, J. L.: Condensation nucleus size distribution at Mawson, Antarctica: Microphysics and chemistry, Atmos. Environ. A-Gen., 27, 1427-1434, https://doi.org/10.1016/09601686(93)90128-1, 1993.

Hamed, A., Joutsensaari, J., Mikkonen, S., Sogacheva, L., Dal Maso, M., Kulmala, M., Cavalli, F., Fuzzi, S., Facchini, M. C., Decesari, S., Mircea, M., Lehtinen, K. E. J., and Laaksonen, A.: Nucleation and growth of new particles in Po Valley, Italy, Atmos. Chem. Phys., 7, 355-376, https://doi.org/10.5194/acp-7355-2007, 2007.

Hansen, A. D. A., Lowenthal, D. H., Chow, J. C., and Watson, J. G.: Black carbon aerosol at McMurdo Station, Antarctica, J. Air Waste Manage., 51, 593-600, 2001.

Hara, K., Hirasawa, N., Yamanouchi, T., Wada, M., and Herber, A.: Spatial distributions and mixing states of aerosol particles in the summer Antarctic troposphere, Antarctic Record, 54, 704-730, 2010

Hara, K., Osada, K., Nishita-Hara, C., Yabuki, M., Hayashi, M., Yamanouchi, T., Wada, M., and Shiobara, M.: Seasonal features of ultrafine particle volatility in the coastal Antarctic troposphere, Atmos. Chem. Phys., 11, 9803-9812, https://doi.org/10.5194/acp-11-9803-2011, 2011a.

Hara, K., Osada, K., Nishita-Hara, C., and Yamanouchi, T.: Seasonal variations and vertical features of aerosol particles in the Antarctic troposphere, Atmos. Chem. Phys., 11, 5471-5484, https://doi.org/10.5194/acp-11-5471-2011, 2011 b.

Hinds, W. C.: Aerosol Technology: Properties, Behavior, and Measurement of Airborne Particles, 2nd Edn., Wiley-Interscience, New York, 1999.

IPCC: Climate change 2013: The physical science basis, Intergovernmental panel on Climate Change, Cambridge University Press, New York, USA, 571-740, 2013.

Ito, T.: Study of background aerosols in the Antarctic troposphere, J. Atmos. Chem., 3, 69-91, https://doi.org/10.1007/bf00049369, 1985.

Jaatinen, A., Romakkaniemi, S., Hao, L. Q., Kortelainen, A., Miettinen, P., Mikkonen, S., Smith, J. N., Virtanen, A., Laaksonen, A., Anttila, T., and Hyvärinen, A. P.: The third Pallas Cloud Experiment: Consistency between the aerosol hygroscopic growth and CCN activity, Boreal Environ. Res., 19, 368-382, 2014.
Jaenicke, R., Dreiling, V., Lehmann, E., Koutsenoguii, P. K., and Stingl, J.: Condensation nuclei at the German Antarctic Station "Georg von Neumayer", Tellus B, 44, 311-317, 1992.

Järvinen, E., Virkkula, A., Nieminen, T., Aalto, P. P., Asmi, E., Lanconelli, C., Busetto, M., Lupi, A., Schioppo, R., Vitale, V., Mazzola, M., Petäjä, T., Kerminen, V.-M., and Kulmala, M.: Seasonal cycle and modal structure of particle number size distribution at Dome C, Antarctica, Atmos. Chem. Phys., 13, 7473-7487, https://doi.org/10.5194/acp-13-7473-2013, 2013.

Kammermann, L., Gysel, M., Weingartner, E., Herich, H., Cziczo, D. J., Holst, T., Svenningsson, B., Arneth, A., and Baltensperger, U.: Subarctic atmospheric aerosol composition: 3. Measured and modeled properties of cloud condensation nuclei, J. Geophys. Res.-Atmos., 115, D04202, https://doi.org/10.1029/2009jd012447, 2010.

Kim, G., Cho, H. J., Seo, A., Kim, D., Gim, Y., Lee, B. Y., Yoon, Y. J., and Park, K.: Comparison of Hygroscopicity, Volatility, and Mixing State of Submicrometer Particles between Cruises over the Arctic Ocean and the Pacific Ocean, Environ. Sci. Technol., 49, 12024-12035, https://doi.org/10.1021/acs.est.5b01505, 2015.

Koponen, I. K., Virkkula, A., Hillamo, R., Kerminen, V. M., and Kulmala, M.: Number size distributions and concentrations of the continental summer aerosols in Queen Maud Land, Antarctica, J. Geophys. Res.-Atmos., 108, AAC8-1-AAC8-10, 2003.

Kwon, T. Y. and Lee, B. Y.: Precipitation anomalies around King Sejong Station, Antarctica associated with El Niño/Southern Oscillation, Ocean and Polar Research, 24, 19-31, 2002.

Kyrö, E.-M., Kerminen, V.-M., Virkkula, A., Dal Maso, M., Parshintsev, J., Ruíz-Jimenez, J., Forsström, L., Manninen, H. E., Riekkola, M.-L., Heinonen, P., and Kulmala, M.: Antarctic new particle formation from continental biogenic precursors, Atmos. Chem. Phys., 13, 3527-3546, https://doi.org/10.5194/acp13-3527-2013, 2013.

Kulmala, M., Vehkamäki, H., Petäjä, T., Dal Maso, M., Lauri, A., Kerminen, V. M., Birmili, W., and McMurry, P. H.: Formation and growth rates of ultrafine atmospheric particles: A review of observations, J. Aerosol. Sci., 35, 143-176, 2004.

Lathem, T. L., Beyersdorf, A. J., Thornhill, K. L., Winstead, E. L., Cubison, M. J., Hecobian, A., Jimenez, J. L., Weber, R. J., Anderson, B. E., and Nenes, A.: Analysis of CCN activity of Arctic aerosol and Canadian biomass burning during summer 2008, Atmos. Chem. Phys., 13, 2735-2756, https://doi.org/10.5194/acp13-2735-2013, 2013.

Leena, P. P., Pandithurai, G., Anilkumar, V., Murugavel, P., Sonbawne, S. M., and Dani, K. K.: Seasonal variability in aerosol, $\mathrm{CCN}$ and their relationship observed at a high altitude site in Western Ghats, Meteorol. Atmos. Phys., 128, 143-153, https://doi.org/10.1007/s00703-015-0406-0, 2016.

Martin, M., Chang, R. Y.-W., Sierau, B., Sjogren, S., Swietlicki, E., Abbatt, J. P. D., Leck, C., and Lohmann, U.: Cloud condensation nuclei closure study on summer arctic aerosol, Atmos. Chem. Phys., 11, 11335-11350, https://doi.org/10.5194/acp-11-113352011, 2011.

Mazzera, D. M., Lowenthal, D. H., Chow, J. C., and Watson, J. G.: Sources of $\mathrm{PM}_{10}$ and sulfate aerosol at McMurdo station, Antarctica, Chemosphere, 45, 347-356, https://doi.org/10.1016/s0045-6535(00)00591-9, 2001. 
Mishra, V. K., Kim, K. H., Hong, S., and Lee, K.: Aerosol composition and its sources at the King Sejong Station, Antarctic peninsula, Atmos. Environ., 38, 4069-4084, https://doi.org/10.1016/j.atmosenv.2004.03.052, 2004.

O’Dowd, C. D., Facchini, M. C., Cavalli, F., Ceburnis, D., Mircea, M., Decesari, S., Fuzzi, S., Young, J. Y., and Putaud, J. P.: Biogenically driven organic contribution to marine aerosol, Nature, 431, 676-680, https://doi.org/10.1038/nature02959, 2004.

Pant, V., Siingh, D., and Kamra, A. K.: Size distribution of atmospheric aerosols at Maitri, Antarctica, Atmos. Environ., 45, 5138-5149, 2011.

Paramonov, M., Kerminen, V.-M., Gysel, M., Aalto, P. P., Andreae, M. O., Asmi, E., Baltensperger, U., Bougiatioti, A., Brus, D., Frank, G. P., Good, N., Gunthe, S. S., Hao, L., Irwin, M., Jaatinen, A., Jurányi, Z., King, S. M., Kortelainen, A., Kristensson, A., Lihavainen, H., Kulmala, M., Lohmann, U., Martin, S. T., McFiggans, G., Mihalopoulos, N., Nenes, A., O’Dowd, C. D., Ovadnevaite, J., Petäjä, T., Pöschl, U., Roberts, G. C., Rose, D., Svenningsson, B., Swietlicki, E., Weingartner, E., Whitehead, J., Wiedensohler, A., Wittbom, C., and Sierau, B.: A synthesis of cloud condensation nuclei counter (CCNC) measurements within the EUCAARI network, Atmos. Chem. Phys., 15, 12211-12229, https://doi.org/10.5194/acp-15-12211-2015, 2015.

Park, J., Sakurai, H., Vollmers, K., and McMurry, P. H.: Aerosol size distributions measured at the South Pole during ISCAT, Atmos. Environ., 38, 5493-5500, https://doi.org/10.1016/j.atmosenv.2002.12.001, 2004.

Pereira, E. B., Evangelista, H., Pereira, K. C. D., Cavalcanti, I. F. A., and Setzer, A. W.: Apportionment of black carbon in the South Shetland Islands, Antartic Peninsula, J. Geophys. Res.-Atmos., 111, D03303, https://doi.org/10.1029/2005jd006086, 2006.

Petters, M. D. and Kreidenweis, S. M.: A single parameter representation of hygroscopic growth and cloud condensation nucleus activity, Atmos. Chem. Phys., 7, 1961-1971, https://doi.org/10.5194/acp-7-1961-2007, 2007.

Pierce, J. R. and Adams, P. J.: Efficiency of cloud condensation nuclei formation from ultrafine particles, Atmos. Chem. Phys., 7, 1367-1379, https://doi.org/10.5194/acp-7-1367-2007, 2007.

Pritchard, H. D., Ligtenberg, S. R. M., Fricker, H. A., Vaughan, D. G., Van Den Broeke, M. R., and Padman, L.: Antarctic ice-sheet loss driven by basal melting of ice shelves, Nature, 484, 502-505, https://doi.org/10.1038/nature10968, 2012.

Rankin, A. M. and Wolff, E. W.: A year-long record of sizesegregated aerosol composition at Halley, Antarctica, J. Geophys. Res.-Atmos., 108, AAC9-1-AAC9-12, 2003.

Rignot, E., Casassa, G., Gogineni, P., Krabill, W., Rivera, A., and Thomas, R.: Accelerated ice discharge from the Antarctic Peninsula following the collapse of Larsen B ice shelf, Geophys. Res. Lett., 31, L18401, https://doi.org/10.1029/2004g1020697, 2004.

Roscoe, H. K., Jones, A. E., Brough, N., Weller, R., SaizLopez, A., Mahajan, A. S., Schoenhardt, A., Burrows, J. P., and Fleming, Z. L.: Particles and iodine compounds in coastal Antarctica, J. Geophys. Res.-Atmos., 120, 7144-7156, https://doi.org/10.1002/2015jd023301, 2015.

Schneider, D. P., Deser, C., and Okumura, Y.: An assessment and interpretation of the observed warming of West Antarctica in the austral spring, Clim. Dynam., 38, 323-347, https://doi.org/10.1007/s00382-010-0985-x, 2012.
Sellegri, K., O’Dowd, C. D., Yoon, Y. J., Jennings, S. G., and de Leeuw, G.: Surfactants and submicron sea spray generation, J. Geophys. Res.-Atmos., 111, D22215, https://doi.org/10.1029/2005jd006658, 2006.

Shaw, G. E.: Optical, chemical and physical properties of aerosols over the antarctic ice sheet, Atmos. Environ., 14, 911-921, https://doi.org/10.1016/0004-6981(80)90004-9, 1980.

Steig, E. J., Schneider, D. P., Rutherford, S. D., Mann, M. E., Comiso, J. C., and Shindell, D. T.: Warming of the Antarctic icesheet surface since the 1957 International Geophysical Year, Nature, 457, 459-462, https://doi.org/10.1038/nature07669, 2009.

Stein, A. F., Draxler, R. R., Rolph, G. D., Stunder, B. J. B., Cohen, M. D., and Ngan, F.: Noaa's hysplit atmospheric transport and dispersion modeling system, B. Am. Meteorol. Soc., 96, 20592077, https://doi.org/10.1175/bams-d-14-00110.1, 2015.

Tomasi, C., Vitale, V., Lupi, A., Di Carmine, C., Campanelli, M., Herber, A., Treffeisen, R., Stone, R. S., Andrews, E., Sharma, S., Radionov, V., von Hoyningen-Huene, W., Stebel, K., Hansen, G. H., Myhre, C. L., Wehrli, C., Aaltonen, V., Lihavainen, H., Virkkula, A., Hillamo, R., Ström, J., Toledano, C., Cachorro, V. E., Ortiz, P., de Frutos, A. M., Blindheim, S., Frioud, M., Gausa, M., Zielinski, T., Petelski, T., and Yamanouchi, T.: Aerosols in polar regions: A historical overview based on optical depth and in situ observations, J. Geophys. Res.-Atmos., 112, D16205, https://doi.org/10.1029/2007jd008432, 2007.

Twomey, S.: The nuclei of natural cloud formation part II: The supersaturation in natural clouds and the variation of cloud droplet concentration, Geofis. Pura Appl., 43, 243-249, https://doi.org/10.1007/bf01993560, 1959.

Vaughan, D. G., Marshall, G. J., Connolley, W. M., Parkinson, C., Mulvaney, R., Hodgson, D. A., King, J. C., Pudsey, C. J., and Turner, J.: Recent rapid regional climate warming on the Antarctic Peninsula, Climatic Change, 60, 243-274, https://doi.org/10.1023/a:1026021217991, 2003.

Virkkula, A., Teinilä, K., Hillamo, R., Kerminen, V. M., Saarikoski, S., Aurela, M., Koponen, I. K., and Kulmala, M.: Chemical size distributions of boundary layer aerosol over the Atlantic Ocean and at an Antarctic site, J. Geophys. Res.-Atmos., 111, D05306, https://doi.org/10.1029/2004jd004958, 2006.

Virkkula, A., Hirsikko, A., Vana, M., Aalto, P. P., Hillamo, R., and Kulmala, M.: Charged particle size distributions and analysis of particle formation events at the Finnish Antarctic research station Aboa, Boreal Environ. Res., 12, 397-408, 2007.

Virkkula, A., Asmi, E., Teinilä, K., Frey, A., Aurela, M., Timonen, H., Mäkelä, T., Samuli, A., Hillamo, R., Aalto, P. P., Kirkwood, S., and Kulmala, M.: Review of aerosol research at the Finnish Antarctic research station Aboa and its surroundings in Queen Maud Land, Antarctica, Geophysica, 45, 163-181, 2009.

Weller, R. and Lampert, A.: Optical properties and sulfate scattering efficiency of boundary layer aerosol at coastal Neumayer Station, Antarctica, J. Geophys. Res.-Atmos., 113, D16208, https://doi.org/10.1029/2008jd009962, 2008.

Weller, R. and Wagenbach, D.: Year-round chemical aerosol records in continental Antarctica obtained by automatic samplings, Tellus B, 59, 755-765, https://doi.org/10.1111/j.16000889.2007.00293.x, 2007.

Weller, R., Minikin, A., Wagenbach, D., and Dreiling, V.: Characterization of the inter-annual, seasonal, and diurnal variations of condensation particle concentrations at Neu- 
mayer, Antarctica, Atmos. Chem. Phys., 11, 13243-13257, https://doi.org/10.5194/acp-11-13243-2011, 2011.

Weller, R., Minikin, A., Petzold, A., Wagenbach, D., and König-Langlo, G.: Characterization of long-term and seasonal variations of black carbon (BC) concentrations at Neumayer, Antarctica, Atmos. Chem. Phys., 13, 1579-1590, https://doi.org/10.5194/acp-13-1579-2013, 2013.

Weller, R., Schmidt, K., Teinilä, K., and Hillamo, R.: Natural new particle formation at the coastal Antarctic site Neumayer, Atmos. Chem. Phys., 15, 11399-11410, https://doi.org/10.5194/acp-1511399-2015, 2015.
Wolff, E. W. and Cachier, H.: Concentrations and seasonal cycle of black carbon in aerosol at a coastal Antarctic station, J. Geophys. Res.-Atmos., 103, 11033-11041, 1998.

Yoon, Y. J., Ceburnis, D., Cavalli, F., Jourdan, O., Putaud, J. P., Facchini, M. C., Decesari, S., Fuzzi, S., Sellegri, K., Jennings, S. G., and O'Dowd, C. D.: Seasonal characteristics of the physicochemical properties of North Atlantic marine atmospheric aerosols, J. Geophys. Res.-Atmos., 112, D04206, https://doi.org/10.1029/2005jd007044, 2007. 